\title{
Beyond LibGuides: The Past, Present, and Future of Online Research Guides
}

\author{
Jon C. Giullian \& Ernest A. Zitser
}

To cite this article: Jon C. Giullian \& Ernest A. Zitser (2015) Beyond LibGuides: The Past, Present, and Future of Online Research Guides, Slavic \& East European Information Resources, 16:4, 170-180, DOI: 10.1080/15228886.2015.1094718

To link to this article: http://dx.doi.org/10.1080/15228886.2015.1094718

\section{Published online: 02 Nov 2015.}

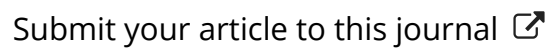

\section{ЏIII Article views: 46}

Q View related articles $₫$ 


\title{
Beyond LibGuides: The Past, Present, and Future of Online Research Guides
}

\author{
JON C. GIULLIAN \\ Watson Library, University of Kansas, Lawrence, Kansas, USA \\ ERNEST A. ZITSER \\ Perkins Library, Duke University, Durham, North Carolina, USA
}

\begin{abstract}
The proliferation of research guides created using the LibGuides platform has triggered extensive discussion touting their benefits for everything from assessment, engagement, and marketing, to outreach and pedagogy. However, there is at present a relative paucity of critical reflection about the product's place in the broader informational landscape. This article is an attempt to redress this lacuna. Relying primarily on examples from the field of Slavic, East European, and Eurasian studies, the authors briefly describe the evolution of online research guides; identify reasons for the proliferation of Springshare's product in academic libraries; question whether LibGuides improve learning or reinforce information inequality in higher education; and propose a way to move beyond LibGuides.
\end{abstract}

KEYWORDS Academic libraries, access to information, higher education, LibGuides, librarians, online research guides, pedagogy, resource guides, scholarly communication

(C) Jon C. Giullian and Ernest A. Zitser

This article was adapted and expanded from the ASEEES Webinar "The World of LibGuides: Thinking Beyond Your University," presented on April 22, 2015, 2:00 PM-3:00 PM EDT. The authors would like to thank the Association for Slavic, Eurasian, and East European Studies for hosting this webinar, which was sponsored by the Task Force on Instruction and Outreach of the ASEEES Committee on Library and Information Resources.

Address correspondence to Jon C. Giullian, Watson Library, University of Kansas, Rm. 519, 1425 Jayhawk Blvd., Lawrence, KS 66046, USA. E-mail: giullian@ku.edu and Ernest A. Zitser, Perkins Library, Box 90195, 230 Bostock Library, Durham, NC 27708-0195, USA. E-mail: ernest.zitser@duke.edu 
Anyone who has ever Googled a topic on Slavic, East European, and Eurasian studies (SEEES) knows that, contrary to popular opinion, not everything is available online, especially when it comes to peer-reviewed publications or research materials on our region of the globe. And much of what does appear on the World Wide Web is usually not free or is flooded by a seemingly ceaseless torrent of commercial advertisements and unreliable or misleading information. In fact, doing academic research on the Web has sometimes been compared to the impossible task of "drinking from a fire hose." The job of librarians, concomitantly, is to make online research more akin to drinking from a water fountain. ${ }^{1}$ Paradoxically, instead of solving the problem of "information overload," this pedagogical imperative has coincided with the simultaneous decrease in the number of Slavic subject specialists at academic libraries and the development and widespread adoption of a commercially licensed tool-Springshare's LibGuides platform-for sharing the intellectual labor of building and creating library resource guides and pathfinders, formerly the task of these self-same subject specialists. The proliferation of LibGuides has triggered extensive discussion touting their benefits for everything from assessment, engagement, and marketing, to outreach and pedagogy. ${ }^{2}$ However, there is at present a relative paucity of critical reflection about the product's place in the broader informational landscape. ${ }^{3}$ This article is an attempt to redress this lacuna. Relying primarily on examples from the field of SEEES, the authors briefly describe the evolution of online research guides; identify reasons for the proliferation of Springshare's product in academic libraries; question whether LibGuides improve learning or reinforce information inequality in higher education; and propose a way to move beyond LibGuides.

\section{EVOLUTION OF ONLINE RESEARCH GUIDES BRIEFLY DESCRIBED}

The precursors to Springshare's LibGuides were paper guides, sometimes in brochure form, that were published in the 1970s. ${ }^{4}$ For example, prior to the emergence of the Internet, subject librarians at the University of Kansas produced in-house paper guides that introduced the major finding aids for a specific subject or discipline. Other terms for research guides included library guides, pathfinders, subject guides, or even finding aids, although the last phrase usually refers to descriptions of archival collections rather than to an index or similar document that helps the user locate items within a specific source. ${ }^{5}$ Regardless of the name or format, the research guide was intended to help students and scholars become more familiar with the basic tools for conducting research in a particular subject or discipline. A classic example from the field of SEEES is Wojciech Zalewski's work Fundamentals of Russian Reference Work in the Humanities and Social Sciences, which was a direct outcome of his dual role as Curator for Russian and East 
European Collections at the Stanford University Libraries and Lecturer in Slavic Bibliography at the Department of Slavic Languages and Literatures at Stanford University. ${ }^{6}$

With the advent of the Internet, the content of paper research guides found its way onto the Web as static pages usually coded manually in HTML or generated from a database of selected resources. ${ }^{7}$ This was the case with Zalewski's publication, which was transferred from print to screen some time in the 1990 s and housed on the servers of Stanford University Library. ${ }^{8}$ The second generation of online research guides was the so-called born-digital guide, that is, a guide specifically designed for the online environment and not based upon previous paper versions. Born-digital guides were typically based at and hosted online by an individual institution and were referred to as "home-grown" guides. The best example of such a guide in the field of SEEES is the Guide to Slavic Information Resources, ${ }^{9}$ created by Slavic librarians at the University of Illinois at Urbana-Champaign (UIUC). This guide was developed using federal (Title VIII) funding from the US Department of State. This same funding is used to support the Slavic Reference Service (SRS), a free year-round service at the University of Illinois, which handles bibliographic and reference questions in all subject areas connected to SEEES. ${ }^{10}$ Like the SRS, UIUC's home-grown guide is a free, publicly-funded, and publicly-available online resource, which is limited only by the human and financial capital invested in this particular institution. Anyone who has ever had the pleasure of using UIUC's Slavic Reference Service or its guide to Slavic information resources knows that the capital (both human and otherwise) responsible for these endeavors is impressive indeed. UIUC's "Slavic Information Resources" guide is an excellent example of a homegrown online research guide that continues to be extremely useful for SEEES. However, precisely because this guide relies on mostly local resources, it is somewhat static and does not take full advantage of the Slavic librarian expertise available beyond the University of Illinois.

Even as far back as 1996, however, librarians were asking the question: "Need each library create its own subject guides? Why not refer to, or copy, the subject guides of others?"11 Until the invention of Web 2.0 applications, however, the notion of one set of universal subject guides sounded like an ideal, if rather utopian, solution to the problems of limited time, server space, and money. Despite their potential benefits and cost savings, "crowdsourced" subject guides were never fully embraced by the profession as a whole, much less SEEES librarians. ${ }^{12}$

\section{PROLIFERATION OF LIBGUIDES}

As the market for technological solutions to the problem of information overload has expanded, and government funding for higher education 
(particularly in SEEES) has declined, privately owned, commercial providers of externally hosted online research guides have stepped in to offer their services. These third-generation guides allow librarians to leave behind the technological side of online guides and to focus on finding, creating, and uploading their content. Although some customization of design is available, the technical side of the platform is managed by an external, third party, rather than by the librarians and researchers who use it, or the institution that subscribes to it (and that pays both information workers' salaries and the company's service fee). Indeed, rather than work with their IT department to come up with an affordable, open-access option, academic, public, and private libraries, as well as museums and some other organizations, have eagerly adopted externally hosted guides. ${ }^{13}$

One of the most popular of these commercial tech fixes to the problem of content management is a product called LibGuides. Created in 2007 by an American ed-tech entrepreneur of South Slavic heritage, ${ }^{14}$ Springshare's brand of online guides has quickly become a national and international tool for academic research. Readers of Slavic E East European Information Resources may be familiar with their own institutional instance of Springshare's product and probably use it with some frequency. Some Slavic librarians, including the authors of the present article, have worked with SEEES faculty to create LibGuides for a specific class or topic, while other information professionals are familiar with this product simply as a matter of course. ${ }^{15}$

Over the past several years the LibGuides platform has taken the library world by storm. At the writing of this article, Springshare boasted " 427,538 hosted guides created by 65,810 librarians at 4799 libraries worldwide." ${ }^{6}$ Both the University of Kansas Libraries and Duke University Libraries, for example, have subscribed to Springshare's LibGuides platform. Slavic librarians at both institutions have created a suite of guides in support of their collections and curricula. ${ }^{17}$ Both institutions include a general guide to the discipline. ${ }^{18}$ Much of the content in these two guides is similar, including lists of key reference sources; catalogs for finding books, theses, and dissertations; and periodical databases for finding journal articles and news articles. ${ }^{19}$

While each guide also contains some unique content, tailored to each institution, ${ }^{20}$ SEEES LibGuides are meant to be part of a larger, Springshareadministered "Community Site," situated beyond the confines of a particular academic host. If you multiply the number of LibGuides at each institution by the hundreds of institutions that use LibGuides, essentially you get a crowd-sourced community of research guides that can be used as discovery tools by virtually anyone on the planet. ${ }^{21}$ Virtuality, however, is the keyword here. For although anyone with a web browser can view the content of any LibGuide in Springshare's community, not everyone has access to all the resources listed on a specific LibGuide. While librarians frequently include 
some free online resources (e.g., open-access journals and digital libraries), access to commercial products (e.g., subscription databases like EBSCO's American Bibliography of Slavic E Eastern European Studies [ABSEES] ${ }^{22}$ is typically regulated by a formal legal contract between the vendor-publisher and the institutional subscriber and blocked by a "pay wall." In practice, therefore, access to the commercial products advertised on LibGuides varies from one (wealthy) institution to another. Many researchers, especially those at smaller institutions, can admire the merchandise on display, marveling at its opulence and availability, but cannot actually afford to use it.

\section{LIBGUIDES AS TOOLS OF EDUCATION OR OPPRESSION?}

The main problem with LibGuides, however, is less a matter of economic inequality than of intellectual and pedagogical poverty. If, as $\mathrm{Xi}$ and Yao Chen have argued, the main purpose of a subject or research guide is to serve as a gateway to subject-specific information, ${ }^{23}$ then librarians are the gatekeepers of a stronghold ("knowledge base") owned by library vendors and leased by university libraries. Regardless of the role that professional librarians actually play in creating or organizing that knowledge, they are treated simply as conduits for the operation of private corporations attempting to arrogate for themselves the control of global flows of information (and capital). The problem is not merely that librarians who use LibGuides are tacitly complicit in this "neo-liberal" enterprise, ${ }^{24}$ but that playing along with the current rules of the game undermines the core values that motivate library practitioners. ${ }^{25}$ In particular, those values emphasize the benefits of universal access to information and the public virtues of a humanistic education, i.e., "information in the service of society," rather than "information workers" in servitude to a corporate entity (the "global university" and the vendors catering to its needs). Does the online research guide, in its current incarnation (LibGuide), really foster the kind of transformative educational experience that we, as library professionals, college teachers, and citizens of the world, deem important? Or does it serve as merely another tool of social oppression?

Although librarians present LibGuides as a new technological tool for improving students' research skills, the guides actually fall short of their pedagogical potential. In the words of Alison Hicks, the typical LibGuide is little more than a librarian-defined list of "best sources," whose aim is to help students to fulfill a "typical research assignment," requiring the composition of a term paper with at least three peer-reviewed articles and at least one book. By presenting "decontextualized lists of key (textual) resources," most guides created using the LibGuides platform misrepresent the very nature of scholarly research, turning what used to be an adventure of discovery into a lifeless, inert formula for cherry-picking among a predetermined menu of options and conducting a few canned searches. ${ }^{26}$ 
In contrast, Hicks recommends designing LibGuides "around research processes," organizing content by "student assignment, need, or habit." She argues further that an even better approach is to help students "create their own LibGuides" in an effort to engage them as "active participants in broader conversations about research and inquiry." ${ }^{27}$ While Hicks recognizes that other platforms (e.g., WordPress) might be better suited to this endeavor, she never questions the utility of LibGuides per se. Nor does she analyze the way in which LibGuides (and other externally hosted products) reinforce existing social inequalities. These inequalities include not only the way independent scholars or researchers from poorly endowed institutions (and regions of the globe) are denied access to information held under strict regimes of copyright protection but also the way subject librarians are treated by the educational institutions that employ them, relegating them to the ranks of service (rather than teaching) staff and mandating the use of Springshare's platform (rather than open-access initiatives) as a way of interacting with the university's "customers." Instead, Hicks winds up "blaming the victim," i.e., librarians themselves, who are (inexplicably) wed to an "industrial-era adherence to library-centric, behaviorist learning theories" and to "librariandefined notions of value and authority." ${ }^{28}$

\section{MOVING BEYOND LIBGUIDES}

If we are to move beyond LibGuides, then we must figure out a way not only to design and use guides in a more pedagogically effective way, but also to change the information ecosystem that makes it all too easy for private companies to profit from the services provided by non-profit educational institutions. And we must do so without turning library professionals against each other. As Hicks's own bibliography demonstrates, librarians who have "started to think about the nature of critical pedagogy" are not as rare as her argument seems to imply. The very existence of Hybrid Pedagogy, the open-access online journal in which Hicks's article critiquing librarians' use of LibGuides has appeared, shows that the problem lies less with the "oppressive" librarians whom she lambastes than with the social environment in which both the supporters and the detractors of critical pedagogy currently operate. As we all know, unless the librarian is teaching his or her own course, s/he has little or no control over which medium (digital or analog) or how the medium is used to organize and deliver educational content. The degree to which any university-approved content management system-be it LibGuides, Blackboard, Sakai, Canvas, Drupal, ${ }^{29}$ or a "homegrown," open-access product, like the one recently developed at the Indiana University Libraries at Bloomington ${ }^{30}$ — can be used as a pedagogical tool depends upon the collaborative relationship between the librarian and the instructor teaching the course. ${ }^{31}$ Ideally, librarian-faculty collaboration would 
exploit the advantages of the existing infrastructure in order to improve the learning process and would use the learning process itself to raise questions about the very infrastructure through which social relations are mediated. Only in this way will the providers of higher education help to transform, rather than merely reproduce, the world in which students, teachers, and librarians currently find themselves.

A larger and more complicated question, however, is how to transform university-sponsored research guides into community-based, distributed online tools given the current climate of copyright and technological restrictions. One model might be to attach resource guides to scholarly societies, such as the Association of Slavic, East European, and Eurasian Studies (ASEEES), or the Slavic and East European Section (SEES) of the Association of College \& Research Libraries (ACRL). One example of such a resource can be found in current practice within area studies librarianship. The Western European Studies Section (WESS) of ACRL has long maintained an extensive online compilation of resources (WESS Web wiki) dedicated to the regions of Western Europe. ${ }^{32}$ Access to resources on WESS Web is neither restricted to one institution nor limited by complex license agreements, but freely accessible to everyone. A similar wiki has also been created by the "librarians, book dealers, scholars, and students" affiliated with the Seminar on the Acquisition of Latin American Library Materials (SALAM). ${ }^{33}$ Building such a resource for the SEEES community is currently on the agenda of the Task Force on Instruction and Outreach of ASEEES's Committee on Library and Information Resources (CLIR), of which the present writers are members. But, as the examples above demonstrate, restructuring the information landscape for the benefit of area studies scholars and the communities they serve lies beyond the scope of a single committee or task force. That kind of effort requires a thorough rethinking of the neo-liberal practices underpinning the current process of scholarly communication, as well as the cooperation of multiple stakeholders, both within and outside academic libraries. In other words, it provides an opportunity for professional librarians to do what they do best: organize, educate, and inspire.

\section{CONCLUSION}

Even if your university does not have its own SEEES librarian, or a subscription to Springshare's LibGuides, access to the World Wide Web makes it possible to tap into the expertise of information specialists assembled (virtually) under the umbrella of the LibGuide community. This commercial enterprise is growing rapidly and has become the de facto network of online research guides for many academic disciplines, including SEEES. It is one example of how the work of individual subject specialists has become transformed into a global resource. But it is also a prime example of how one 
private company can use its platform to corner the market, re-package content using a non-profit educational institution's own labor force, and then sell that content back to them at an over-inflated price. ${ }^{34}$

Whatever one's level of experience with this commercial product, its proliferation may be problematic for academic libraries and academic librarians in ways that are similar to other online licensing agreements that serve to restrict and limit library autonomy. The similarity between LibGuides's business model and the one that has led to the current crisis in scholarly journal publishing is not coincidental. Both are a product of the same social and cultural forces responsible for the "McDonaldization" of academic libraries and higher education across the globe. ${ }^{35}$ Both exploit educational institutions' weaknesses, including but not limited to a lack of fiscal support sufficient to support IT infrastructure; inadequate relationships between IT services and other campus units, including the libraries; an increasing "adjunctification" of university faculty and staff; and an unduly restrictive copyright regime that limits access to information needed by faculty, students, and the public in general. Any discussion about the future of online research guides, especially at institutions of higher education, consequently, must figure out ways of identifying and redressing these institutional weaknesses. If this brief, but critical survey of the history of online research guides helps to advance that conversation, and makes it possible for us to imagine and begin building a world beyond LibGuides, then it will have served its purpose.

\section{NOTES}

1. Victorian Association for Library Automation, Drinking From a Fire Hose: Managing Networked Information: Victorian Association for Library Automation, 7th Biennial Conference and Exhibition (Melbourne, Australia: Victorian Association for Library Automation, 1993). See also Christopher J. Frank and Paul F. Magnone, Drinking From the Fire Hose: Making Smarter Decisions Without Drowning in Information (New York, NY: Portfolio Penguin, 2011). The fountain of knowledge or fount of wisdom metaphor can be traced as far back as the writings of Saint John of Damascus (c. 675/6-749), also known as Chrysorrboas (literally "streaming with gold"-i.e., "the golden speaker"). According to the logic of this comparison, librarians have finally inherited the mantle of the Church Fathers, but have done so at precisely the wrong time, i.e., at a point when new information technology (Web 2.0) and new pedagogical initiatives (such as "flipped classrooms") have ostensibly made the "sage on the stage" completely obsolete.

2. A search "libguides or subject guides" in Library Literature E Information Science Index, (https://www.ebscohost.com/academic/library-literature-information-science-index, by subscription), for example, retrieves 328 secondary sources.

3. As Alison Hicks has noted, "[y]ou have to be a pretty tenacious researcher to find any criticism about LibGuides." Alison Hicks, "LibGuides: Pedagogy to Oppress?" Hybrid Pedagogy, http://www. hybridpedagogy.com/journal/libguides-pedagogy-to-oppress/ (accessed April 16, 2015).

4. Brenda Reeb and Susan Gibbons, "Students, Librarians, and Subject Guides: Improving a Poor Rate of Return," Portal: Libraries \& the Academy 4, no. 1 (2004): 129.

5. Nedelina Tchangalova, "Subject Guides: Putting a New Spin on an Old Concept," Electronic Journal of Academic and Special Librarianship 9, no. 3 (2008), http://southernlibrarianship.icaap.org/ content/v09n03/tchangalova_n01.html (accessed October 15, 2015). 
6. Wojciech Zalewski, Fundamentals of Russian Reference Work in the Humanities and Social Sciences, with a foreword by Terence Emmons, Russica bibliography series, 5 (New York, NY: Russica Publishers, 1985). See also J. S. G. Simmons, Russian Bibliography, Libraries, and Archives: A Selective List of Bibliographical References for Students of Russian History, Literature, Political, Social and Philosophic Thought, Theology and Linguistics (Twickenham, UK: Anthony C. Hall, 1973). For a brief discussion of the pedagogy underpinning these types of guides, see Michael Brewer and Ernest A. Zitser, "Slavic Information Literacy: Past, Present, and Future," Slavic E East European Information Resources 10, no. 2-3 (2009): 117-24; and Michael Brewer and Ernest A. Zitser, "Isn't There an iPhone App for That? Information Literacy for Students of Slavic, Eurasian, and East European Studies," NewsNet: News of the American Association for the Advancement of Slavic Studies 49, no. 5 (2009): 1-5.

7. Martin P. Courtois, Martha E. Higgins, and Aditya Kapur, "Was This Guide Helpful? Users' Perceptions of Subject Guides," Reference Services Review 33, no. 2 (2005): 188.

8. Wojciech Zalewski, "Russian Reference Works," Stanford University Libraries, http://web. stanford.edu/dept/SUL/library/prod/depts/hasrg/slavic/3refint.html (accessed May 11, 2015). [Editor's note: Stanford has now taken that server down. As a result, the online version of Zalewski's guide is no longer available. Efforts are being made to put it back up in the not-too-distant future.]

9. University of Illinois, Slavic Reference Service, "Slavic Information Resources," http://www. library.illinois.edu/spx/webct/index.html (accessed October 12, 2015).

10. Helen Sullivan, "Slavic Bibliography Online: WebCT as a Resource for Online Instruction," Slavic \& East European Information Resources 3, no. 1 (2002): 21-33; Teresa E. Tickle, "Expanding Outreach to a Unique User Community: The Slavic Reference Service and the Internet," The Reference Librarian 67-68, (1999): 69-83; Angela Cannon, "Digital Reference in Slavic and East European Studies with an Examination of Practice at the University of Illinois and the Library of Congress," Slavic E East European Information Resources 6, no. 2-3 (2005): 183-217.

11. Colin Askew, "University Library Provision of Subject Guides to the Internet," New Review of Information and Library Research 2, (1996): 73.

12. Hugh K. Truslow, "States of Transition: Slavic Studies Research Guides and Information Literacy," Slavic E East European Information Resources 10, no. 2-3 (2009): 276-88.

13. On the lack of IT resources and coordination between libraries and IT departments as an obstacle to creating local, institutional, online research guides, see Karen E. Niemla, "President's Column: Friends Don't Let Friends Use LibGuides," Codex: Journal of the Louisiana Chapter of the ACRL 3, no. 1 (2014): 9-20, http://journal.acrlla.org/index.php/codex/article/view/96 (accessed October 15, 2015).

14. Slaven Zivkovic (B.Sc., Computer Engineering, Santa Clara University, 1997), the CEO of Springshare, touts the fact that he worked as a library assistant at his undergraduate alma mater, a private non-profit Catholic university in San Francisco's Bay Area that promotes itself as "the Jesuit university in Silicon Valley." See "About Springshare," http://www.springshare.com/about.html (accessed October 15, 2015); and Santa Clara University, FYI: News for the Campus Community: The Faculty-Staff Newsletter 4, no. 5 (2004), http://www.scu.edu/fyi/nov1504.cfm\#three (accessed October 15, 2015).

15. Experience with LibGuides has become part of the repertoire of skills expected of new librarians entering the field. Whereas in the previous decade job-seekers may have been asked about their HTML skills, some library job postings include experience with LibGuides either as a required or preferred qualification.

16. Springshare, LLC, "LibGuides Community Site," http://libguides.com/community.php (accessed August 24, 2015).

17. Jon Giullian, "ALL Slavic \& Eurasian Studies Guides: Subject \& Course Guides," University of Kansas Libraries, http://guides.lib.ku.edu/sesguides (accessed October 12, 2015); Ernest Zitser, "My Guides," Duke University Libraries, http://guides.library.duke.edu/profile.php?uid=4242 (accessed October 12, 2015).

18. Jon Giullian, "Russian, East European, and Eurasian Studies (REES): Home," University of Kansas Libraries, http://guides.lib.ku.edu/sesguide (accessed October 12, 2015); Ernest Zitser, "Slavic, Eurasian, and East European Studies: Getting Started," Duke University Libraries, http://guides.library. duke.edu/slavicstudies (accessed October 12, 2015).

19. Niemla has argued that the lack of diversity among the LibGuides of different institutions is less a failure of imagination on the part of subject librarians than a direct consequence of Springshare's corporate strategy and price structure (Niemla, "President's Column: Friends Don't Let Friends Use LibGuides"). LibGuides has a variable pricing model for different features: some customization of design is possible for an extra fee, over and above the standard subscription rate. The fact that subscribing institutions are 
charged based on full-time enrollment (FTE), rather than a flat fee suggests the company's pricing structure reflects a deliberate attempt to market LibGuides as a database product rather than as a web-hosting service. As Niemla points out, this move not only allows the company to charge more for its product, but is also a way to stake a claim to the intellectual property (content) uploaded to Springshare's servers.

20. For example, the Special Collections page on Duke's Slavic, Eurasian, and East European Studies site: http://guides.library.duke.edu/content.php?pid=11342\&sid=76817.

21. For example, a search for slavic in the LibGuides Community retrieves 31 guides, and a search for russian retrieves 47 guides related to SEEES in general-guides that serve as gateways to the discipline. These numbers are low considering the number of librarians responsible for Slavic or Russian studies. One might also notice that the LibGuides from many large Slavic libraries or Slavic collections are missing from the list, including the University of Kansas's LibGuides. The reason for such low numbers and the absence of some guides is due to the fact that some libraries have moved over to LibGuides version 2.0, which is still under development. Thus, the current LibGuides Community includes only those institutions that are currently still using LibGuides version 1.0.

22. ABSEES is another example of a formerly free, librarian-generated resource that was purchased by a commercial vendor and then sold back (at a marked-up price) to academic libraries. For the early history of ABSEES, see Maria Gorecki Nowak, "Report on ABSEES (The American Bibliography of Slavic and East European Studies)," Slavic E East European Information Resources 1, no. 4 (2001): 79-82; Aaron Trehub, "Building a World Bibliography of Slavic and East European Studies: ABSEES, EBSEES, and Beyond," Slavic E East European Information Resources 3, no. 2-3 (2002): 106-9; and Marianna Tax Choldin, "My Life in Libraries," Slavic E East European Information Resources 10, no. 4 (2009): 363.

23. Xi Chen and Yao Chen, "Gateway to East Asian Studies: An Analytical Report of Subject Guides in North American East Asian Libraries," Journal of East Asian Libraries 157, (2013): 157-70.

24. Mark Olssen and Michael A. Peters, "Neoliberalism, Higher Education and the Knowledge Economy: From the Free Market to Knowledge Capitalism," Journal of Education Policy 20, no. 3 (2005): 313-45; Jonathan Cope, "Neoliberalism and Library \& Information Science: Using Karl Polanyi's Fictitious Commodity as an Alternative to Neoliberal Conceptions of Information," Progressive Librarian 43, (2014-2015): 67-80; Samuel E. Trosow, "The Commodification of Information and the Public Good: New Challenges for a Progressive Librarianship," Progressive Librarian 43, (2014-2015): 17-29. Thanks to Diana Greene for bringing the latter two articles to our attention.

25. American Library Association, "Core Values of Librarianship," http://www.ala.org/advocacy/ intfreedom/statementspols/corevalues (accessed October 12, 2015).

26. Hicks, "LibGuides: Pedagogy to Oppress?" Hicks's article echoes the argument of Barbara Fister, "Smoke and Mirrors: Finding Order in a Chaotic World," (paper presented at the Workshop for Instruction in Library Use, University of Guelph, Ontario, May 19 2005), http://homepages.gac.edu/ fister/WILU2005. html. Fister suggested that ACRL's Information Literacy Competency Standards for Higher Education (http://www.ala.org/acrl/standards/informationliteracycompetency) take the creativity, originality, and intellectual curiosity out of the research process, turning research into a "hopelessly mechanistic" process decorated by "oversimplified external signs" of what represents a legitimate or useful source.

27. Hicks, "LibGuides: Pedagogy to Oppress?"

28. Ibid.

29. Karen Rondestvedt, the former Slavic specialist at Stanford, reports that Stanford University Libraries are in the process of rolling out their own version of online research guides based on the open source platform, Drupal. Although the Drupal platform might be a bit clunkier than LibGuides, developers have been responsive to complaints and suggestions. The cooperative relationship between Stanford's IT unit and the libraries is one of the most important aspects of this project. All labor is performed by university staff and recompensed by the university. Consequently, there is no third party (vendor) taking advantage of library staff labor without paying for it.

30. Wookjin Cheun, "Slavic and East European Studies," Indiana University Bloomington Libraries, https://libraries.indiana.edu/slavic-and-east-european-studies (accessed October 12, 2015). Although the Indiana and Stanford guides resemble the previously-mentioned, second generation, "home-grown guides," these new platforms are Web 2.0 content management systems that do not require editors to have specialized IT skills such as HTML coding. They do require cooperation between librarians and IT staff, as well as the support of university administrators who are committed to open-source products.

31. See Jon Giullian, "Slavic Folklore, the Library, and the Web: A Case Study of Subject-Specific Collaborative Information Literacy at the University of Kansas," Slavic \& East European Information Resources 10, no. 2-3 (2009): 200-20; Terri Tickle Miller, "Information Literacy for Slavic Studies Faculty: 
A Multi-Tiered Approach to Better Communication," Slavic \& East European Information Resources 10 , no. 2-3 (2009): 235-43.

32. ACRL, "Western European Studies Section," main page, http://wessweb.info/index.php/ Main_Page (accessed October 12, 2015).

33. Seminar on the Acquisition of Latin American Library Materials (SALALM): http://salalm.org/ wiki/index/ (accessed October 12, 2015).

34. For other examples, see Søren Mørk Petersen, "Loser Generated Content: From Participation to Exploitation," First Monday 13, no. 3 (2008), http://firstmonday.org/article/view/2141/1948 (accessed October 15, 2015).

35. K. P. Nicholson, "The McDonaldization of Academic Libraries and the Values of Transformational Change," College and Research Libraries 76, no. 3 (2015): 328-38. doi: $10.5860 / \mathrm{crl} .76 .3 .328$. 